\title{
Concept of the Russian language teaching in the course of the US policy
}

\author{
I.Z. Bulatova ${ }^{1 *}$, and A.A. Bilyalova ${ }^{1}$ \\ ${ }^{1}$ Department of Philology, Kazan Federal (Volga Region)University, Naberezhnye Chelny, Russian \\ Federation
}

\begin{abstract}
As the modern world gives many opportunities for travel, communication, technologies, the need of learning foreign languages has become the critical issue for every country. The more expanded borders are, the more forces should be undertaken for controlling the situation within and out of the country. The concept of the Russian language teaching in the course of the US policy depends on political matters. The author has made an effort to describe activities of strengthening educational system for international understanding and global competence. The analyzed data includes the list of the US schools, which offer Russian language courses, the campaigns which are run for re-enforcing the position of the Russian language. This article describes the existing measures, which provide Russian language learning in the USA. The study analyses the ways of implementing the Russian language into the system of higher, secondary and primary schools. The findings indicate the measures of the Russian Federation government, which are successfully performed on the territory of the USA. The study demonstrates the changes of methodical potential, which have been undergone since $60^{\text {th }}$ of XX century.
\end{abstract}

\section{Introduction}

The total number of people who independently speak Russian in North America, Australia, and Oceania is 4.1million, the USA and Canada hold the leading positions [1]. The demand for the study of the Russian language has been fluctuating since 1980 when the number of Russian language learners was low but the interest in the Russian language escalated in 1989-1991. After that, the popularity of the Russian language subsequently fell, but by the beginning of the 2000s, interest in learning the Russian language began to grow again.

Foreign language is a test of stability for a language, so the task of preserving the language, in our case the Russian language, should be of a national character. The relevance of this study is determined by the fact, that Russian is the only one among 10-12 leading world languages, which over the past 25 years has been steadily losing its position in all major regions of the world [1]. Every Russian-speaking emigrant must realize that the issue of language preservation is not only the state task of the USA and the Russian Federation, but it is the task of internal self-awareness. This is a complex problem and to simplify it requires to provide appropriate and effective support of the Russian language on the

\footnotetext{
* Corresponding author: harkins_89@mail.ru
} 
territory of the USA. This study aims the existing concept of the Russian language teaching in the USA. For fulfilling the aim of the research, the following objectives are stated:

-to demonstrate the contribution of the US government to the Russian language teaching,

-to learn the number of American universities, schools which offer Russian language courses,

-to analyze the input of the Russian Federation into distributing of the Russian language on the territory of the USA.

A number of questions regarding issues of the Russian language teaching are explored by Oksana Laleko, I.V.Zenkevich, A.L.Arefiev $[1,2,3]$. They reflect anxiety about the level of the Russian language usage in Russian-speaking diasporas. In comparison to the Chinese and Korean languages, which are taught by numerous schools, the Russian communities have a significant lag in this matter.

\section{Methodologies}

The study has been fulfilled with the help of analysis of documentary sources, press materials, private materials of statistics, and official cites of American schools and universities. We focused our research on analyzing the curriculum of schools, colleges, universities in different regions of the USA. The paper has conducted content analyses of online Russian-speaking, American periodicals.

\section{Results}

The concept of learning Russian considers a national security issue for the United States. The American radio station "Voice of America" announced the return of the Russian language to the list of the most popular foreign languages studied in the United States. At the same time, "Radio Svoboda" reports that after the collapse of the Soviet Union, there was a sharp decline in those wishing to study Russian in the United States. However, in 2006 , teaching the "great and mighty" along with some other languages was called "critical" for the US national security. Today Russian is one of the ten most popular foreign languages among American university students [3].

The document, signed by the Minister of Education and Science of the Russian Federation and the Minister of Education of the United States, was launched on May 24, 2002. "The USA - Russia: Improving the Quality of Research and Learning Activities in Higher Education" program, which involves partnerships between Russian and American universities, especially in the field of learning English in Russia and the Russian language in the United States to promote understanding between the two nations. In the United States, this program is funded by Title VII of the Higher Education Act with the support of the Department of Education and the Federal Foreign Language and Area Studies (FLAS) program [4].

Teaching and learning languages cover the national demand of the state, which is assigned to the matters of the country's national security. This strategy got a large impact after the tragic events of September 11, 2001, which forever changed the American mind.

Zenkevich I.V. in her research "Russian studies in the USA in the XXI century: the Russian language in American education" describes the education system of the USA as a bridge for implementing the strategy for world domination, confrontation to terrorism [4]. The same approach to education is described in the reports "Education for global leadership: the importance of international studies and foreign language education for US economic and national security”," Foreign languages and higher education: new structures 
for a changing world ". The minor languages which are understood as all languages of the world, except Spanish, French, German are worth learning nowadays because the creation of coalitions and alliances calls for additional resources, new participants, and cooperations. Chinese, Arabic, Hindi, Urdu, Japanese, Russian, Korean, and Turkish are among them $[5,6]$.

The ideology of national security is supplemented by the "Startalk" grant program, which promotes the dissemination of languages, which are critical for the United States, the Russian language is included in the list. The program was overseen by the National Security Agency. "Startalk" offers teachers and students short-term summer training and professional development programs [4]. The Utah State Education Committee reports that Utah is home to 30,000 Russian-speaking citizens, moreover, the University of Utah is known as the participant of the "Startalk" program. They were the first ones, who organized Russian language classes in a form of camp [7].

As a rule, the demand for a particular language is estimated by the number of students enrolled in it. But, in the case of minor languages like Russian, Ukrainian, Arabic, Hindi, Persian, it is difficult to immediately predetermine their future fate. In this case, linguists use a tactical - strategic approach based on the supply and demand of the modern market. The demand dictates those specific tasks for the implementation of which knowledge of a foreign language is required, whereas proposals are responsible for the available language competencies and technologies. The state request depends on the events, taking place within the country in a specific period, and the possible alignment of subsequent events, namely, what the surplus for the country and society is predicted from the implementation and financing of the program. Thus, the ratio of needs and abilities (Capacity / Needs) is a formula for calculating the rationality of implemented programs.

According to the Center for Applied Linguistics (CAL), there are Russian-English schools operating under the immersion program, which are run by $\mathrm{K}-12$ †program: in Cincinnati, Ohio, at the Academy of World Languages, in Baltimore, at the Baltimore International Academy School, in Anchorage, at Turnagain Elementary School, in Portland, at Kelly Elementary School, in Turnagain, at Anchorage's Turnagain Elementary School [8]. Unfortunately, statistical data do not always reflect the full picture, due to the fact that statistics are compiled on the basis of data provided by the educational institutions themselves, and it can be assumed that there are educational institutions that simply did not send information to the Center.

Another basis of Russian schools abroad are schools at Russian embassies. In the USA the secondary school within the Russian Embassy in the United States (Washington DC) was established in 1957. Children of employees of Russian foreign missions, representative offices, and branches of various companies, families of compatriots, and immigrants from countries study there [9].

State sponsorship of academic linguistic programs has difficulties in organizations, so in this case teaching of Russian language is fulfilled by private bilingual schools, mostly run by former emigrants from Russia or post-Soviet countries. "Russian-American International School" is a full - time school, located in San-Francisco prepares students through a bilingual integrated curriculum with a strong emphasis in Math and Science (Physics, Chemistry, and Biology), at the same time Music and PE are systematically integrated into the learning process [10].

\footnotetext{
$\dagger \mathrm{K}-12$ (spoken as "k twelve", "k through twelve", or "k to twelve"), from kindergarten to 12th grade, is an American expression that indicates the range of years of supported primary and secondary education found in the United States, which is similar to publicly supported school grades prior to college in several other countries, such as Afghanistan, Australia, Canada, Ecuador, China, Egypt, India, Iran, the Philippines, South Korea and Turkey.
} 
Today the Higher Education System has contributed to teaching the Russian language by including Russian language courses into their curriculum. Although the number of courses is little, the opportunity of learning the Russian language is spread throughout the whole territory of the USA. Students, applying for courses in the Russian language, can get Bachelor's, Master or Post-Graduate degrees at these universities.

The table below (Table 1) demonstrates the list of the US universities, which provide a possible number of Russian language classes. The data is presented by the "Hotcourses International" website, which contains the information about accredited institutions based in 48 countries worldwide [10].

Table 1. The universities of the US, which provide Russian language course.

\begin{tabular}{|c|c|c|c|c|c|}
\hline $\begin{array}{l}\text { The name of } \\
\text { school }\end{array}$ & $\begin{array}{c}\text { № of } \\
\text { courses }\end{array}$ & $\begin{array}{c}\text { The name of } \\
\text { school }\end{array}$ & $\begin{array}{c}\text { № of } \\
\text { courses }\end{array}$ & The name of school & $\begin{array}{c}\text { № of } \\
\text { courses }\end{array}$ \\
\hline $\begin{array}{l}\text { Arizona State } \\
\text { University }\end{array}$ & 1 & $\begin{array}{c}\text { Syracuse } \\
\text { University }\end{array}$ & 1 & $\begin{array}{l}\text { University of } \\
\text { Maryland }\end{array}$ & 1 \\
\hline Boston University & 1 & $\begin{array}{l}\text { Texas A\&M } \\
\text { University }\end{array}$ & 1 & $\begin{array}{c}\text { University of } \\
\text { Wisconsin - Madison }\end{array}$ & 3 \\
\hline Brooklyn College & 1 & $\begin{array}{c}\text { The Kent State } \\
\text { University }\end{array}$ & 2 & Vanderbilt University & 1 \\
\hline $\begin{array}{c}\text { Colleges of Contra } \\
\text { Costa }\end{array}$ & 1 & $\begin{array}{c}\text { The Ohio State } \\
\text { University }\end{array}$ & 1 & $\begin{array}{l}\text { University of Illinois } \\
\text { at Urbana Champaign }\end{array}$ & 2 \\
\hline $\begin{array}{l}\text { Columbia } \\
\text { University }\end{array}$ & 3 & $\begin{array}{c}\text { The University of } \\
\text { Vermont }\end{array}$ & 1 & $\begin{array}{c}\text { University of } \\
\text { Michigan - Ann } \\
\text { Arbor }\end{array}$ & 3 \\
\hline Dartmouth College & 2 & $\begin{array}{l}\text { University of } \\
\text { Missouri }\end{array}$ & 1 & $\begin{array}{l}\text { University of } \\
\text { Minnesota }\end{array}$ & 1 \\
\hline $\begin{array}{l}\text { Diablo Valley } \\
\text { College }\end{array}$ & 1 & $\begin{array}{l}\text { University of } \\
\text { Wisconsin - } \\
\text { Milwaukee }\end{array}$ & 1 & $\begin{array}{l}\text { University of } \\
\text { Pennsylvania }\end{array}$ & 1 \\
\hline Duke University & 3 & $\begin{array}{l}\text { University of } \\
\text { Pittsburgh }\end{array}$ & 1 & $\begin{array}{c}\text { University of } \\
\text { Colorado Boulder }\end{array}$ & 2 \\
\hline $\begin{array}{l}\text { Florida State } \\
\text { University }\end{array}$ & 2 & $\begin{array}{c}\text { University of } \\
\text { Illinois at Chicago }\end{array}$ & 2 & University of Arizona & 2 \\
\hline $\begin{array}{c}\text { George Washington } \\
\text { University }\end{array}$ & 1 & $\begin{array}{c}\text { University of Los } \\
\text { Angeles }\end{array}$ & 2 & $\begin{array}{c}\text { University of New } \\
\text { Hampshire }\end{array}$ & 1 \\
\hline $\begin{array}{l}\text { Michigan State } \\
\text { University }\end{array}$ & 1 & $\begin{array}{c}\text { University of } \\
\text { Kansas }\end{array}$ & 1 & $\begin{array}{l}\text { University of New } \\
\text { Mexico }\end{array}$ & 1 \\
\hline $\begin{array}{l}\text { New York } \\
\text { University }\end{array}$ & 2 & $\begin{array}{c}\text { University of } \\
\text { Chicago }\end{array}$ & 3 & $\begin{array}{c}\text { University of } \\
\text { Southern California }\end{array}$ & 1 \\
\hline $\begin{array}{c}\text { Pennsylvania State } \\
\text { University Park } \\
\text { Campus }\end{array}$ & 3 & $\begin{array}{l}\text { University of } \\
\text { Texas at Austin }\end{array}$ & 2 & Virginia Tech & 1 \\
\hline $\begin{array}{l}\text { Portland State } \\
\text { University }\end{array}$ & 1 & $\begin{array}{c}\text { University of } \\
\text { California Davis }\end{array}$ & 1 & Yale University & 4 \\
\hline
\end{tabular}

Theodore Gerber, the author of "The State of Russian Research in the United States", describes the results of a survey among students of 36 American universities at various levels and faculty. When choosing a university, he was guided by the availability of courses in Russian (or other Slavic) language, literature, and culture, the presence of exchange programs with Russia, the presence of a resource center for Russian and East European Studies (REES). Despite the difficulties experienced by faculties and departments working in the field of Russian studies, in the 1990s and 2000s, universities managed to preserve them, and to strengthen the positions of such departments and cooperation with other faculties and departments, new narrowly focused Russian courses are being developed: 
Russian for businessmen, Russian for sociologists or courses in contemporary Russian art and literature in Russian at Indiana University[11].

To encourage undergraduate students to study Russian, there is a Flagship Program run by Portland State University, University of California, The University of WisconsinMadison, which provides scholarships to study in Russia. The prospects for the development of Russian language teaching programs depend on comprehensive measures, including the creation of a favorable environment for teaching Russian as one of the rarely taught in the United States. At the same time, 24 universities conducted summer Russian language courses in 2011. Among them, there is a number of elite universities, including Berkeley, University of Chicago, Harvard, Indiana University, University of Illinois, University of Washington, University of Wisconsin, University of Michigan, University of Pittsburgh, University of Virginia, and the University of California at Los Angeles.

Scientific and educational ties between our countries are not weakening. Over the fifteen years from 2000 to 2015, at least eight scientific conferences about Russia were held in the United States, more than 80 scientific and more than 50 public lectures are read a year, about fourteen round tables are held, more than 30 screenings of films and other cultural events dedicated to Russia are held. Exchange programs with Russian universities remain popular, for example, Harvard University, whose Faculty of Slavic Languages and Literatures is considered one of the best in the country, continues to fund the trips of its students and teachers to conduct scientific research in Russia, and also invites specialists from Russia to read courses and seminars, accepts Russian doctoral students (at least once annually)

On November 10, 2019 the Russian Cultural Center in Washington hosted an international scientific-practical conference "Topical issues of teaching Russian language and literature." The participants prepared a program that covered a wide variety of aspects of education at all stages of education - from kindergartens to universities. The universities continue to hold conferences on Russian studies, which bring together not only specialists but also the general public, which is interested in obtaining information about Russia. However, at the same time, the lack of personnel, funding, public or private is a problem. The state funding allocated for the study of the Russian language and regional studies related to Russia is reduced: for example, several FLAS programs (Foreign Language and Area Studies) were closed, the total number of people enrolled in foreign languages has also decreased: from 1,621,059 in 2009 to 1,522,070 in 2013 (the programs of French, German, Italian, Japanese, and Arabic also lacked students in this period), only Chinese programs showed growth [4].

\section{Discussion}

Teaching of Russian language is not only a personal priority, what is more, it is not the duty of only one country. At least two countries both the Russian Federation and the USA are in high engagement for distributing of Russian language on the territory of the USA and throughout the world. The secondary education system in the United States does not imply teaching Russian as a foreign language, and today only a limited number of schools have in their curriculum the discipline of RFL. In public schools, Russian is usually taught in high school as a foreign language and is an elective course, the same as cooking, woodworking, and playing musical instruments.

Most often, students of large schools (more than 1000 students) have the opportunity to study Russian, where it is taught on an equal basis with other foreign languages: Spanish, French, German, Chinese, Japanese. In addition to the secondary education system, church parishes, public organizations, and associations are responsible for teaching the Russian language, the number of their students enumerate several thousand people [12]. 
In addition to the political component, it is necessary to pay tribute to the fact that compulsory linguistic education contributes to the comprehensive development of the individual, including critical and creative thinking, cognitive abilities, intercultural communication skills, acceptance and respect for cultures of different countries and peoples, education of tolerance and awareness of oneself as a part of a large multicultural world, whose borders are open to almost everyone. Some states are introducing the discipline of RFL (Russian as a Foreign Language) instead of other disciplines, and some states have successfully implemented the Russian bilingual program (Russian Dual Program).

Besides American schools, which work out on spreading the Russian language, the Russian Cultural Center in Washington expands the circle of young people who are interested in Russian culture, among the members not only people with Russian heritage but Americans and other nationality people. Learning about national traditions through visiting diplomatic missions is one of the most popular trends, which is actively supported by the Russian Cultural Center. Within this ideology and support of the "Embassy Adoption Program", on the 1st of June 2019, an International Children's Day took place. The schoolchildren visited the representative halls of the Russian diplomatic mission, got acquainted with its history, and also presented their concert program, performing Russian folk dances and dances.

The annual educational campaign "Total Dictation" is being held for the seventeenth time. The main goal is to increase literacy for native speakers of the Russian language, as well as popularizing Russian among those who study it [13].

The United States hosted the International Linguistic Olympiad "Russian Bear Cub " with the participation of schoolchildren from Maryland, Virginia, Massachusetts, California, North Carolina, as well as students of the secondary school of the Russian Embassy in the United States. The total number of participants in the event was 250 people. Conducting Olympiads abroad is the most important factor in preserving the Russian language among the children of compatriots [14].

Another important campaign, which is on the duty of the Russian Cultural Center in Washington is the organization of the Russian assessment examination. It gives possibilities for those, who apply for the Russian Federation citizenship. The program is also recommended for people who are willing to test their Russian language skills.

The "Russian Cultural Center" in Washington is always in a tense link with the Russian government and supports all representatives of their center on the territory of the USA. The biggest representative and mediator of Russian teaching program is "Rosinka" - a bilingual school in San Jose, California. Rossinka teaches children according to the programs of Russian schools, allowing students to take exams according to Russian standards, to study in schools and universities in Russia. Schoolchildren also, attend additional entertaining and academic classes [15].

The particular development of teaching the Russian language in the United States is given by teachers of the Russian language departments at US universities. A team of teachers under the leadership of E.V. Zagrai, in the article "Studying and Teaching Russian Language and Culture in the State of New Mexico, USA" outlines the main points of Russian language learning, which is processed by the University of New Mexico. The strategy of their methodology differs from the other universities by applying the Russian language into the other spheres, as economics, international affairs, criminology, sociology, and others [16]. M.V. Avery, a teacher from New Orleans, USA, represents her own author's class "Magpie. Russian language for children " in the article "Features of teaching RFL to children 7-9 years old in the United States". The described course is designed for both children whose native language is English and children from Russian-speaking families (bilingual children). The principal of the program is in "worksheets" (pre-prepared 
exercises in the form of templates), methods of oral advance - the predominance of oral speech over writing, a game form of training, an adaptation of complex material for a beginner level[17].

The evolution of methodical literature has been escalated significantly since 1958 . According to the American Association of Teachers of Slavic and East European Languages (AATSEEL), there were no books for teaching RLF [18]. The first emergence of the textbook on RFL, "Russian for all", published by the "Institute of the Russian language of A.S. Pushkin" dates back to the mid-80s. A group of authors under the leadership of V.G. Kostomarov brought together the most prominent experts in RFL of that time. The published book was a real complex, which included a collection of exercises, a manual for the development of speech, a book for reading, an appendix with gramophone records, a grammar reference book, and a dictionary. Today, the methodical support of teaching RFL is holding firm, the book market is saturated with multiple editions of teaching complex, based on the communicative approach. A detailed description of teaching materials is presented by S.V. Abramova, E.G. Azimov in the article "American textbooks on RFL" $[19,20]$. Their study gives a review to the basic methodical literature in the teaching of RFL. The books are established from the point of different proficiency of the language from elementary to advanced, the most well-known among them: "A Basic Russian Course", "Start / Nachalo", "Advanced Russian Through History / Affairs of bygone days", "Advanced Russian: From Reading to Speaking. An Interactive Multimedia Language Course", "Russian in Use: An Interactive Approach to Advanced Communicative Competence" "The Russian Word's Worth: A Humorous and Informative Guide to Russian Language Culture and Translation".

\section{Conclusion}

The successful functioning of the concept of maintaining minor languages by the US intends to contribute to the strengthening of international relations not only in the political arena but also in the market and other spheres.

Our results demonstrated that responsibility for teaching foreign languages rests with local governments based on local state requests, some states are introducing the discipline of RFL instead of other disciplines, and some states have successfully implemented the Russian bilingual program (Russian Dual Program). The United States cannot be associated only with an understanding of the political expediency and national security strategy, it fits into the general concept of teaching foreign languages in the country.

The study has demonstrated an advantage in following the methods of quantitative research by analyzing data of universities, schools, language, and cultural centers.

The present findings confirm that expatriates in metropolitan areas and large developed cities have a greater advantage, as Russian cultural centers offer language classes, coordinate workshops on various aspects of Russian culture, including folklore, music, Russian cooking (for example, the New Russia Cultural Center in Albany, New York), as well as organize other events to celebrate Russian cultural heritage.

We have found out that teaching of the Russian language in the USA is in control of the following organizations:

- US Department of Defense - through the program of STARTALK, which provides learning opportunities for American students and teachers, the US authority has been reinforcing their national security since 2006 .

- Higher educational system - more than 45 universities of the USA provide professional Bachelor, Master, Post-graduate degrees in Slavic languages. An existing "Flagship program" promotes study in Russia for American students by the sources of scholarships and student exchange programs. 
- Elementary and Secondary educational system - public and private schools create conditions for implementing the Russian language. The Russian language classes are promoted as elective ones. Another way of spreading the Russian language on the territory of the USA is running Russian-English bilingual schools, including Russian schools in the Embassy of the USA. They are popular among children of emigrants, expatriates, or children with Russian heritage.

- Informational portals "The Russian world", "The Russian Cultural Center in Washington" are in high responsibility for provoking interest in Russian culture and heritage. Their role is to organize campaigns, which plan to have long-term forecasting results.

Future studies could investigate the qualitative and quantitative ratio between the measures undertaken for teaching Russian in the USA and the way of evolving the Russian language in the world arena. The more interest in the Russian language today - the more abilities for conservation and development of the Russian language for the next generations. This may consider an investigation of the model of the Russian language in the future: the appropriate usage of oral and written speech norms, the functioning of the rules of morphology, lexicology, orthoepy, syntax, punctuation under the influence of the English language. The presence of these programs indicates the desire to study the Russian language in the United States. Despite the contradictions between our countries, the relationships between the USA and the Russian Federation remain at a stable level. World leadership is impossible without international contacts, which depend on knowledge of foreign languages and cultures.

The reported study was funded by RFBR according to the research project № 20-31-70001.

\section{References}

1. Arefiev, A.L. "Russian language in the education system of the countries of the world", Facets of Russian education. Center for Sociological Research, Moscow.: 83124, (2015).

2. Laleko, O. “Assessing Heritage Language Vitality: Russian in the United States", Heritage Language Journal, 10(3), 89-102, (2013).

3. Avetisyan A. " Learning Russian as a US National Security Strategy ”, Voice of America: [electronic resource]: URL https://www.golosameriki.com/a/russianlanguage-as-part-of-us-national-strategy/3458725.html,(2016).

4. Zenkevich I.V. "The state of Russian studies in the United States in the XXI century: The place of the Russian language in the system of American education", report, Bulletin of Tomsk State Pedagogical University, (2017).

5. Barker, C. "Education for international understanding and global competence". report, Carnegie Corporation of New York, USA, (2000).

6. Ad Hoc Committee on Foreign Languages. "Foreign languages and higher education: new structures for a changed world ", Profession, pp. 234-245, (2007).

7. Bolotov, S. “Americans learn Russian for National Security”, Ridius: [electronic resource]: URL https://www.ridus.ru/news/229076], (2016).

8. Center for Applied Linguistics: [electronic resource]: URL https://www.cal.org/.

9. Grammar Russian School by the Russian Embassy in the USA, official cite : [electronic resource]: http://resw.us/svedeniya-o-shkole.html. 
10. Hotcourses abroad, official cite : [electronic resource]:

https://www.hotcoursesabroad.com/study/training-degrees/us-usa/russian-languagecourses/loc/211/cgory/fn.364-4/sin/ct/programs.html.

11. Gerber Theodore P. The State of Russian Studies in the United States: an assessment by the association for Slavic, East European and Eurasian Studies. July 2015. ASEEES, Pittsburgh, (2015).

12. Abramova, S. V. Teaching the Russian language in the American school, Russian language in the school. - № 9, pp. 74-80, (2011).

13. Editorial staff of the portal "Russian World. "Total dictation has united compatriots in different countries": [electronic resource]: https://russkiymir.ru/news/279254/, (2020).

14. Editorial staff of the portal "Russian Cultural Centre in Washington". " The USA hosted the International Linguistic Olympiad "Russian Bear Cub - Linguistics for everyone": [electronic resource]: http://usa.rs.gov.ru/ru/news/20617?category_id=8, (2019).

15. Editorial staff of the portal "Russian World." "San Jose Bilingual School receives grants": [electronic resource]: https://russkiymir.ru/news/279458/, (2020).

16. Zagray E.V., Ivanova - Sullivan T.D. Mayer I.V., Patterson E.V., Shkireva A.O. "Study and teaching of the Russian language and culture in the state of New Mexico, USA", Russian language abroad. Special issue, Russian Studies of the United States of America, pp. 9-15, (2017).

17. Avery M.V. "Features of teaching RFL to children 7-9 years old in the USA", Russian language abroad. Special issue. Russian Studies of the United States of America, pp. 25 - 27, (2017).

18. American Association of Teachers of Slavic and East European Languages. "Teaching Russian in American Secondary Schools", The Slavic and East European Journal" Vol. 2, No. 3, pp. 241-249, (1958).

19. Abramova S.V., Azimov E.G. "Modern American textbooks on RFL ", Russian language abroad "№ 2 b pp. 32 - 41, (2013).

20. Rifkin B. "Materials for Teaching Russian", The Learning and Teaching of Slavic Languages and Cultures / Edited by Olga Kagan \& Benjamin Rifkin with Susan Bauckus. Indiana, (2000). 